from such an examination often leads to better planning and better returns. The fact that animal feeding-stuffs may now be bought freely on an open market will allow new plans to be put into practice.

This meeting gives us the opportunity of hearing about some aspects of the problem that lies ahead of us in providing rations for our livestock and to examine the ways in which our new knowledge can be translated into farming practice.

\title{
The Changing World Supply of Animal Feeding-stuffs
}

By H. R. Humphries, Animal Feeding Stuffs Division, Ministry of Food, Dean Bradley House, Horseferry Road, London, S.W.I

The total supply of feeding-stuffs in the world to-day is similar to, or possibly greater than, that in $1938-9$, but this fact is only part of the picture. Most pronounced changes have occurred in the location of these supplies and particularly in the quantities entering into international trade.

The prewar tonnage of feeding-stuffs available in the United Kingdom was $9,400,000$ tons exclusive of any home-grown grain. The details are given in Table I, from which it should be noted that about $6,000,000$ tons were imported and $3,400,000$

Table 1. Average prewar (1934-8 average) supply of concentrated feeding-stuffs excluding home-grown grain

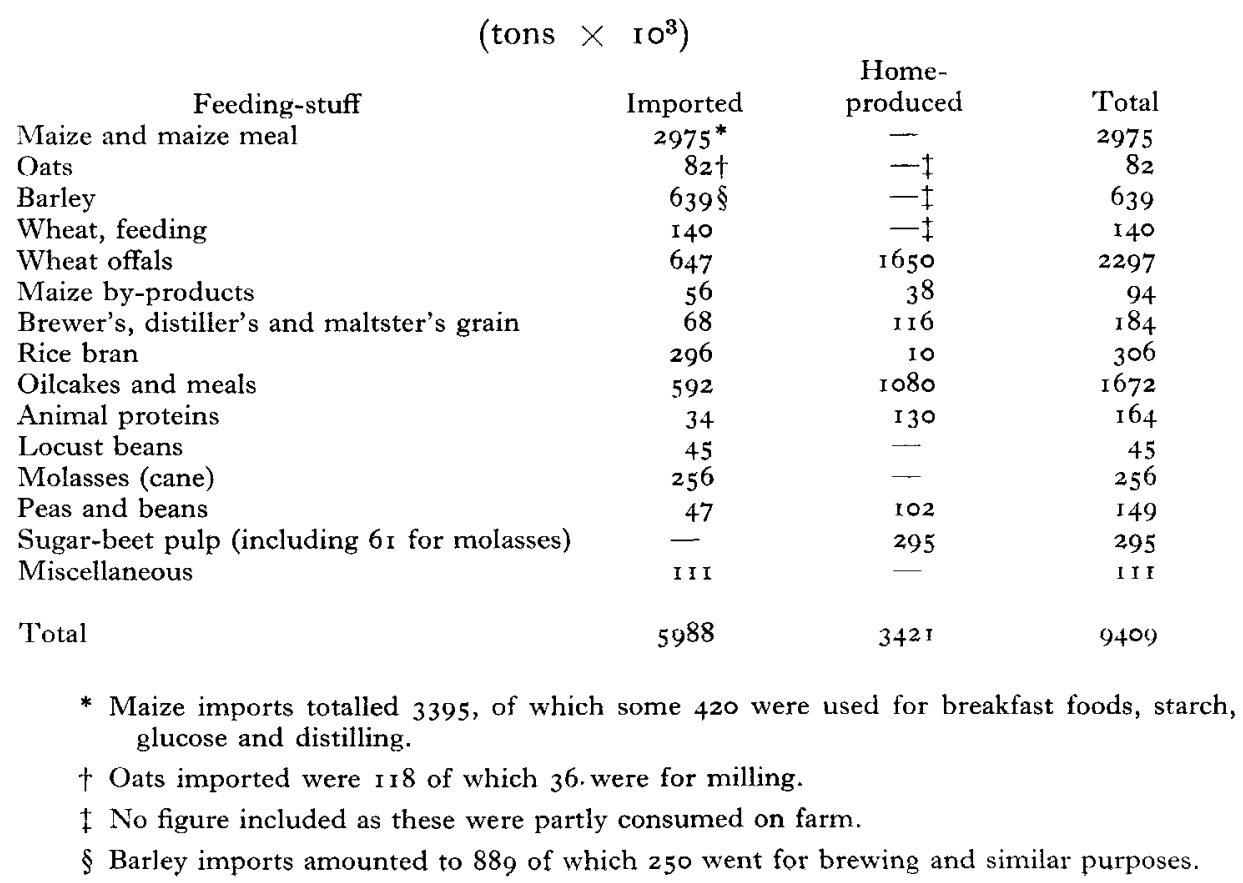


tons produced at home, but out of the home production about $2,400,000$ tons were made from imported oilseeds and wheat.

This paper is concerned with a detailed examination of the world supply of the principal feeding-stuffs.

\section{Cereals}

Maize. World production in 1952 was $127,000,000$ tons compared with I $2,000,000$ tons in 1938 . The main producer was the U.S.A. with $82,000,000$ tons in 1952 , against $64,000,000$ tons in 1938 . Our main prewar supplier was Argentina with $2,550,000$ tons, and if that country had had normal harvests there would have been no dollar problem with supplies. The production in Argentina dropped from a prewar production of $8,000,000$ tons to $1,000,000$ tons in $1950,2,670,000$ in $195 \mathrm{I}, 2,040,000$ in $195^{2}$ and $3,620,000$ in 1953 . The future supply for importing countries, including the U.K., would appear to depend upon the availability of dollars until Argentina can readjust her production. The supplies from other sources are small in volume and cannot always be relied upon.

Barley. The world supply has increased from $3^{6,000,000}$ tons to $43,000,000$ tons. The principal increases have occurred in Canada and the United Kingdom. The home production has risen from 900,000 tons to over 2,250,000 tons, and this has enabled the needs of the brewers, maltsters and distillers to be met and a substantial increase in the supply for animal feeding to be provided. The prospects are good for the next 12 months and no difficulty should be found in maintaining the supplies at a high level.

Oats. The world supply shows almost no change. Home production is slightly higher and the big reduction in the supply needed for horses means that ample supplies for other livestock are available without imports.

Wheat offals. From a position of acute shortage the prospects have recently undergone a change for the better. The flour extraction rate in most countries has been lowered because of the increased wheat production, with a consequent increase in available supplies of offals. Home production is likely to improve both in quality and quantity consequent upon the decision to permit the production of white flour. The volume available may, however, not reach prewar levels for another year or so.

Rice bran. Burma, our principal supplier, has dropped her production from 300,000 to 85,000 tons. French Indo-China and Thailand have also reduced production. Rice bran is a most valuable feed, and it is unfortunate that large supplies cannot now be obtained.

Summary of position with cereals. The cereal position shows that there should be no difficulty in maintaining a satisfactory level of supplies provided no harsh restrictions are imposed on allocations of foreign currencies-especially of dollars.

The following points should be noted of the international markets: ( $x$ ) world trade in maize has declined from $8,250,000$ to $4,250,000$ tons, (2) world trade in barley has advanced from $2,250,000$ to $5,000,000$ tons, principally because Japan is taking over $1,000,000$ tons to replace rice for human food, and (3) oats have 
increased from 658,000 to $1,699,000$ tons, owing almost entirely to the trading of 950,000 tons by Canada to U.S.A.

\section{Vegetable proteins}

Let us now examine in a similar manner the position with protein feeds, which has undergone the greatest change. This is due to governmental action by India, war action in Korea and changes in policy by other countries. Table 2 compares the supplies of different types of oilcakes in the prewar period and the present

\section{Table 2. Estimated supplies of oilcakes in the United Kingdom}

$$
\text { (tons } \left.\times 10^{3}\right)
$$

\begin{tabular}{|c|c|c|c|c|c|c|c|}
\hline \multirow[b]{2}{*}{ Type of seed } & \multicolumn{3}{|c|}{ I.938 } & \multicolumn{4}{|c|}{ Average $195^{1-2}$} \\
\hline & $\begin{array}{c}\text { Cake } \\
\text { imports }\end{array}$ & $\begin{array}{l}\text { Available } \\
\text { from seed } \\
\text { imports }\end{array}$ & Total & $\begin{array}{l}\text { Cake } \\
\text { imports }\end{array}$ & $\begin{array}{l}\text { Available } \\
\text { from seed } \\
\text { imports }\end{array}$ & Total & $\begin{array}{c}\text { Gain or loss } \\
\text { in comparison } \\
\text { with } 1938\end{array}$ \\
\hline $\begin{array}{l}\text { Cottonseed } \\
\text { Groundnuts }\end{array}$ & $\begin{array}{l}268 \cdot 5 \\
280 \cdot 4\end{array}$ & $\begin{array}{l}517 \cdot 2 \\
186 \cdot 9\end{array}$ & $\begin{array}{l}785 \cdot 7 \\
467 \cdot 3\end{array}$ & $\begin{array}{r}\operatorname{I09} \cdot 8 \\
29.5\end{array}$ & $\begin{array}{l}100 \cdot 6 \\
151 \cdot 3\end{array}$ & $\begin{array}{l}210.4 \\
180.8\end{array}$ & $\begin{array}{l}-575.3 \\
-286.5\end{array}$ \\
\hline Linseed & 53.7 & 196.6 & $250 \cdot 3$ & $92 \cdot 3$ & 18.1 & I $10 \cdot 4$ & -139.9 \\
\hline Rapeseed & 18.1 & I5.I & $33 \cdot 2$ & 3.2 & 2.5 & $5 \cdot 7$ & $-27 \cdot 5$ \\
\hline Soya beans & $7 \cdot 9$ & $80 \cdot 2$ & $88 \cdot 1$ & $43 \cdot 3$ & $3^{6 \cdot 9}$ & $80 \cdot 2$ & $-\quad 7.9$ \\
\hline Sunflower & - & - & -- & 138.5 & - & 138.5 & +138.5 \\
\hline Sesame & $7 \cdot 5$ & - & $7 \cdot 5$ & $6 \cdot 5$ & $5 \cdot 4$ & II $\cdot 9$ & $+\quad 4.4$ \\
\hline Copra & $4 \cdot 3$ & $4 \mathrm{I} \cdot 7$ & $46 \cdot 0$ & $5 \cdot 2$ & $52 \cdot 5$ & $57 \cdot 7$ & +117 \\
\hline Palm kernels & $4 \cdot 8$ & $70 \cdot 7$ & $75 \cdot 5$ & 6.7 & $202 \cdot 5$ & $209 \cdot 2$ & +133.7 \\
\hline Other kinds & 17.8 & $4 \cdot 5$ & $22 \cdot 3$ & 19.8 & 22.9 & $42 \cdot 7$ & +20.4 \\
\hline Total & 663.0 & I I 12.9 & 1775.9 & 454.8 & $592 \cdot 7$ & 1047.5 & $-728 \cdot 4$ \\
\hline
\end{tabular}

times. In $195 \mathrm{I}-2$ the total supply was conditioned to an agreed ration pool. That restriction no longer exists and, though total supplies may increase, it is really the composition of this total that is interesting.

Cottonseed cake. The reduction in the quantities imported has been remarkable. The main cause has been the action of Egypt in reducing her cotton acreage and also in using her production at home partly for feed, but mainly for fuel. Supplies from other sources have been about normal, except from India which dropped out of this market many years ago. The loss from India will be felt by those who fatten cattle and sheep. There is still a good supply of decorticated cake available, as the loss is mainly from undecorticated cake.

Groundnut cake. The loss of supplies of both seed and cake from India accounts for the whole reduction. India prohibited the export of oilcakes in I94I, and in 1946 took similar action about oilseeds. The production in India is slightly greater than in the prewar period, but her cake is now being used as fertilizer.

The U.K. has had to rely upon supplies of seed from West Africa. It is fortunate that production in Nigeria improved, or the picture would have been a very gloomy one, not that it can be called bright now.

India's action has curtailed the supply of seeds and cakes to Europe by $1,153,000$ tons (expressed as cake), of which the United Kingdom's share was 575,000 tons. It is true this was not all groundnut, but $70 \%$ of the seed ( 835,000 tons) and $80 \%$ 
of the cake ( 365,000 tons) exported from India before the war consisted of decorticated groundnuts. Unless India revives the export trade in groundnuts the prospects for the future are poor.

The production in Argentina of seed has increased from a prewar figure of 77,000 to 173,000 tons in 1953 .

Linseed cake. The drop is very heavy, influenced partly by India, but mainly by Argentina. From a prewar production of I,500,000 tons, Argentina's harvest in 1953 is 571,000 tons. The world supply of linseed is $10 \%$ lower than before the war and is mostly consumed in the country of origin.

Sunflower-seed cake. This is a new venture for the U.K. and in the decorticated form the seed has been well received. The development of sunflower growing in Argentina has enabled a fair import of cake to be made, but supplies are limited. The 1953 crop of 528 , 000 tons was only half that of 195 I, namely I,02 I, 000 tons.

Soya-bean-cake meal. The world's production has expanded by about onethird owing to developments in the U.S.A. Dollars and the war in Korea have been the chief reasons why the U.K. and Europe have not enjoyed the benefit of the world's increase. Better times may be ahead.

Palm kernels. The need for oil for margarine has necessitated an increase in the importation of palm kernels. Supplies could be bought for sterling from West Africa, and the increase in production here of palm-kernel cake and extracted palm-kernel meal is providing a problem of how to dispose of it to the economic advantage of both the Government and the livestock feeder. Any help in developing a good market here will be welcomed.

Dried yeast. This is very scarce.

Summary of position with vegetable proteins. Although the volume of supplies may increase slightly, the pattern cannot change materially except for a possible increase in soya-bean products. The world trade in oilseeds before the war was $8,700,000$ tons with a cake equivalent of $5,700,000$ tons. This had declined in 1952 to $4,200,000$ tons with a cake equivalent of $2,400,000$ tons.

In oilcakes a prewar total of $3,250,000$ tons has dropped to $2,000,000$ tons. This contraction in world trade has reduced the oilcake supplies in Europe from $6,600,000$ to $3,100,000$ tons, and all European countries are affected.

\section{Animal-protein feeds}

Fish meal and meat meal. The home production of fish meal is around 78,000 tons. Imports this year by the Government are 29,000 tons. The home production of meat meal is 26,000 tons and imports of whale-meat meal are 22,000 tons. Further imports by private traders of fish meal and meat meal may reach 40,000 tons, making 195,000 tons available in the country, which is greater than the tonnage available before the war. The prospects of supplies continuing at or near this level are favourable, but with the rapid increase in price that has occurred and which is likely to be maintained the demand may fall.

Dried milk. Supplies of dried skim milk and dried whey continue to be about 20,000 tons/year. 


\section{Restrictions}

All controls of animal feeding-stuffs have now been revoked. Future supplies will depend upon the activities of private traders. No restriction has so far been placed upon their spending of any currency, including dollars, and if this continues there should be a greater supply than during the past few years. In addition the restriction upon the use of home-grown wheat has been withdrawn, and this should give poultry keepers access to supplies previously denied to them.

\section{The Contribution of Grazing to the Nutrition of Farm Animals}

By A. S. Barker and W. S. Ferguson, Fealott's Hill Research Station, Bracknell, Berks.

British farming is mainly devoted to livestock production, since $70-75 \%$ of the total value of all products sold off our farms is attributable to livestock, and nearly $50 \%$ to cattle and sheep. Approximately four-fifths of our total crop production, including grass, is used for animal feeding, supplemented by an annual importation of some $3^{-4}$ million tons of animal feeding-stuffs. Grass production is much the most extensive way of using agricultural land in the U.K. and of some 48 million acres, excluding $\mathrm{I} 7$ million acres of uncultivated rough grazings, threefifths of the cultivated land is in grass.

Grass, therefore, is much the most important single crop in British farming and the main source of livestock food; in fact, it provides about twice the amount of nutrients obtained from all other sources combined. If annual food consumption of livestock is measured in terms of starch equivalent (S.E.), imports supply about $10 \%$ of the total, tillage crops and their by-products some $25 \%$, and the balance, i.e. $65-70 \%$, is supplied in grass. These proportions refer to food consumption by all livestock, including pigs and poultry which eat little grass, and therefore will not apply to the grass-eating animals. Between 80 and $90 \%$ of the total food intake of all cattle and sheep is obtained from grass but this proportion will vary considerably between the different types of grazing livestock. Obviously grass will be a relatively less important contributor to the diet of milk cows than with other cattle and sheep.

Conserved grass, hay, silage and dried grass, is used in the feeding of dairy cows to a much greater extent than in the feeding of other cattle and sheep and commonly provides about one-third of the winter food of the milk cow, or nearly onefifth of her total annual consumption. Over the grazing season fresh grass supplies about three-quarters of the nutrient requirements of the cow. Over the year grass, in average practice, is the source of more than half the total food of cows.

The point is illustrated by the data from the Milk Marketing Board (1953) which indicate that about $55 \%$ of the energy nutrients eaten annually by cows are, 